\title{
SELF-OWNERSHIP AND DESPOTISM: LOCKE ON PROPERTY IN THE PERSON, DIVINE DOMINIUM OF HUMAN LIFE, AND RIGHTS-FORFEITURE*
}

\author{
By JOHAN OLSTHOORN
}

\begin{abstract}
This essay explores the meaning and normative significance of Locke's depiction of individuals as proprietors of their own person. I begin by reconsidering the long-standing puzzle concerning Locke's simultaneous endorsement of divine proprietorship and self-ownership. Befuddlement vanishes, I contend, once we reject concurrent ownership in the same object: while God fully owns our lives, humans are initially sole proprietors of their own person. (Our property rights in our life and body are restricted to possession, use, and usufruct.) Locke employs two conceptions of "personhood": as expressing legal independence vis-à-vis humans and moral accountability vis-à-vis God. Humans own their person in the first sense. As original proprietors of their own person, individuals are entitled to subject themselves to self-chosen authorities, thereby incurring obligations of obedience. But they may not choose just any authority. Divine ownership of human life delimits personal self-ownership by restricting the ways in which humans can dispose of their persons: we cannot possibly consensually subject ourselves to absolute and arbitrary power. Locke's rightsforfeiture theory for crime makes slavery and despotism nonetheless potentially rightful conditions. I argue that, paradoxically, divine dominium of human life underpins both the impermissibility of voluntary enslavement and the justifiability of penal slavery. My analysis helps explain why modern Lockean theories of self-ownership that reject Locke's theological premises have adopted an ambiguous stance toward despotic rule.
\end{abstract}

KEY WORDS: John Locke, self-ownership, property in the person, voluntary slavery, natural rights, natural law, rights-forfeiture, social contract of government, despotism, Roman law

\section{INTRODUCTION}

John Locke (1632-1704) is commonly regarded as the token proponent, if not the originator, of "self-ownership" — the idea that humans have pre-institutional property rights in their person and the products of

* For constructive feedback on earlier drafts of this essay, I am indebted to Laurens van Apeldoorn, Gustaaf van Nifterik, Luciano Venezia, and audiences at Antwerp and Nottingham Universities. The editors and other contributors to this special issue provided unusually helpful comments and suggestions, as did an anonymous referee. Many thanks to all of you. 
their labor. ${ }^{1}$ Indeed, Locke gave a hallmark statement of this view: "every Man has a Property in his own Person. This no Body has any Right to but himself. The Labour of his Body, and the Work of his Hands, we may say, are properly his" (ST §27). ${ }^{2}$ Incontrovertible as this passage seems, whether and to what extent Locke endorses the self-ownership thesis remains disputed. As is often noted, Locke appears to limit, if not undermine, the case for self-ownership by unreservedly embracing divine proprietorship of human life. All human beings are "the Servants of one Sovereign Master, sent into the World by his order and about his business, they are his Property, whose Workmanship they are" (ST §6). God's ownership rights in us restrict our autonomy: they generate a duty to preserve ourselves and rule out agreement to certain forms of political subjection. How to reconcile divine dominium by dint of creation with the idea that each human is by nature "Master of himself, and Proprietor of his own Person" (ST §44)?

A sizable literature has sprung up debating how, if at all, the two ownership claims can be reconciled. The apparent contradiction disappears, this essay argues, once we stop conflating property in our person with property in our lives. In the very paragraph where suicide is prohibited by appeal to divine workmanship, Locke contradistinguishes "disposing of one's person" with "destroying oneself." "But though this be a State of Liberty, yet it is not a State of Licence, though Man in that State have an uncontroleable Liberty, to dispose of his Person or Possessions, yet he has not Liberty to destroy himself" (ST §6). Lockean individuals, I contend, have original full ownership rights in their person but not in their lives and bodies. A few other scholars have made this point before. ${ }^{3}$ This essay advances on their leads by examining what the absolute freedom to dispose of one's person and possessions means, and how personal self-ownership relates to divine ownership of human life.

Locke's conception of personhood is inspired, I suggest, by Roman law categories, partly due to the dynamics of responding to Robert Filmer. Full original ownership of our person means, first and foremost, that we are all born free-sui iuris, our own master. All forms of personal subjection are the consequence of human actions (engaging in commitments or crime). To dispose of one's person is to conditionally subject oneself to another, who henceforth acquires authority over one (that is, obtains a right over one's person,

\footnotetext{
${ }^{1}$ Abbreviations and editions used of works by Locke. ECHU: An Essay Concerning Human Understanding, ed. P. H. Nidditch (Oxford: Clarendon Press, 1975). ELN: "Essays on the Laws of Nature," in Locke: Political Essays, ed. Mark Goldie (Cambridge: Cambridge University Press, 1997), 79-133. FT: "First Treatise," in Two Treatises of Government, ed. Peter Laslett (Cambridge: Cambridge University Press, 1988), 141-263. ST: "Second Treatise," in Two Treatises of Government, ed. Peter Laslett (Cambridge: Cambridge University Press, 1988), 265-428.

${ }^{2}$ Barbara H. Fried calls these lines "the locus classicus for the libertarian conception of selfownership" in "Left-Libertarianism: A Review Essay," Philosophy and Public Affairs 32, no. 1 (2004): 70. Also, e.g., Michael Otsuka, Libertarianism without Inequality (Oxford: Clarendon Press, 2003), 2.

${ }^{3}$ See footnote 22
} 
correlating in obligations of obedience). For Locke, initial full self-ownership thus expresses absolute original independence from human authority as well as rights of civil and political self-determination. It is not expressive of unlimited rights in our life or body - the ultimate owner of which is God. ${ }^{4}$

These qualifications might seem peripheral to modern Lockean theories of self-ownership. My quibbles exclusively concern Lockean rights in one's life and person, not rights to external resources. I will not here dispute that Lockean persons have full and exclusive rights in their labor and the products of their labor-doctrines central to libertarian theories of property. Yet given persistent concerns about the indeterminacy of the concept of self-ownership, ${ }^{5}$ it is worthwhile to consider anew the question of what exactly people own when they own themselves. ${ }^{6}$ This essay reveals that for Locke, self-ownership has a narrower and more definite meaning than is commonly supposed.

Locke's conception of personal self-ownership raises a question of enduring theoretical significance. Self-ownership is standardly substantiated as a set of property rights people have in their bodies or persons. Full liberal ownership includes the power to rent, sell, and mortgage the thing owned. Does this mean that humans qua self-owners are free to sell themselves into slavery and bonded labor? Proponents of self-ownership can forestall this illiberal outcome by arguing that self-enslavement is either impossible or morally impermissible. ${ }^{7}$ How easily the impossibility of selfenslavement can be established depends on what we assume the object of self-ownership to be. If, for instance, we take the alienable thing to be ourselves-dignified human beings-then the sale in a sense destroys the thing. Running some such line of argument is more difficult if, like Locke, we hold that self-owners own their person and understand personal self-subjection as agreeing to be governed by another. Why would selfenslavement be impossible, while agreement to be ruled by a boss or politician is not? This essay argues that Locke invoked a premise external to self-ownership to establish the impossibility of voluntary subjection to

\footnotetext{
${ }^{4}$ I will treat "self-ownership" and "property in the person" as interchangeable and expressing original ownership/proprietorship of one's person (rather than one's life). Carole Pateman insists that the two concepts ought to be kept distinct. In her view, "self-ownership" trades on the "political fiction" that labor power is an alienable commodity, while "property in the person" renders salient the relations of power and subordination involved in labor contracts. For Locke, however, any right that individuals have in virtue of owning a thing is in principle alienable. Carole Pateman, "Self-Ownership and Property in the Person: Democratization and a Tale of Two Concepts," Journal of Political Philosophy 10, no. 1 (2002): 20-53.

${ }^{5}$ For example, Richard Arneson, "Lockean Self-Ownership: Towards a Demolition," Political Studies 39, no. 1 (1991): 54; Fried, "Left-Libertarianism." Cf. Peter Vallentyne, Hillel Steiner, and Michael Otsuka, "Why Left-Libertarianism is Not Incoherent, Indeterminate, or Irrelevant: A Reply to Fried," Philosophy and Public Affairs 33, no. 2 (2005): 203-208.

${ }^{6}$ Cf. Daniel C. Russell, "Self-Ownership as a Form of Ownership," in The Oxford Handbook of Freedom, ed. David Schmidtz and Carmen E. Pavel (Oxford: Oxford University Press, 2018), 31-32.

${ }^{7}$ On this distinction, see Danny Frederick, "The Possibility of Contractual Slavery," The Philosophical Quarterly 66, no. 262 (2016): 47-64.
} 
despotic government-divine dominium of human life. This helps explain why modern Lockean theories of self-ownership that reject Locke's theological premises have dithered about the legitimacy of self-enslavement.

The essay unfolds as follows. After dissecting the current debate on the compatibility of self-ownership and divine proprietorship (Section II) and developing a rival interpretation (Section III), I will argue that divine proprietorship curtails individual rights to dispose of one's person. Divine dominium grounds individual rights and duties of self-preservation. We must preserve ourselves and the rest of humanity on pain of violating God's ownership rights in human life; the joint duties of others correlate in my individual rights to life and bodily integrity. Duties of self-preservation underpin Locke's argument for the impossibility of both self-enslavement and the consensual establishment of absolute and arbitrary government. Both kinds of rule presuppose forms of personal subjection incompatible with God's dominium. Divine proprietorship of human life thus delimits original self-ownership in one's person: humans lack full moral control over which relations of personal subjection they can enter (Section IV). Section V explores Locke's theory of rights-forfeiture. Locke combines robust claims about natural rights in our own person with unsettlingly permissive views about capital punishment and penal enslavementraising a range of questions about the theoretical coherence of his political commitments. I argue that divine proprietorship is the lynchpin between self-ownership and rights-forfeiture. As the owner of our lives, God has the moral power to authorize humans to be killed and enslaved for crime. Divine dominium thus both explains the impossibility of self-enslavement and the justifiability of penal slavery. I conclude with some reflections on the logical connections between self-ownership and voluntary slavery.

\section{Divine Proprietorship versus Human Self-Ownership}

Every human being, Locke writes, is by nature "Master of himself, and Proprietor of his own Person, and the Actions or Labour of it" (ST §44). At the same time, he is adamant that "Men being all the Workmanship of one Omnipotent, and infinitely wise Maker ... they are his Property, whose Workmanship they are" (ST §6). How, if at all, can self-ownership and divine proprietorship be reconciled?

Some scholars regard the two positions as "clearly incompatible." 8 For while God's dominium renders suicide impermissible, self-owners putatively have the right to kill themselves. This tension leads Michael Zuckert to posit a "shift to self-ownership from divine proprietorship" in the Second Treatise-a "stunning reversal." ${ }^{\prime 9}$ His argument hinges on a moot reading

${ }^{8}$ For example, J. P. Day, “Locke on Property,” Philosophy Quarterly 16, no. 64 (1966): 215.

${ }^{9}$ Michael P. Zuckert, Natural Rights and the New Republicanism (Princeton, NJ: Princeton University Press, 1994), 221, 240; also 244. 
of Locke's claim that a slave who has forfeited his life may "draw on himself the Death he desires" by resisting his master's will (ST §23). Zuckert glosses this passage as saying that slaves have a right to commit suicide indirectly. That would prove that Locke eventually "settles the question definitively in favour of self-ownership" — "the true grounds of his natural law ... doctrine." 10 Whatever the merits of Zuckert's Straussian reading, his contention is undermined by Locke's invocation of "the Workmanship of their own Maker, the Almighty" later on (ST §56), as well as by the central role divine ownership of human life plays in Locke's main argument for the impossibility of consensually establishing arbitrary government (Section IV).

A popular harmonizing solution holds that God and humans have different kinds of rights in the same thing. Humans are entrusted with rights of use and usufruct in their life, while God retains ultimate ownership and thus the right to reclaim our lives. Brian Tierney, for instances, avers that the two ownership theses are "not contradictory" since humans own themselves "as a sort of trust from God."11 "[W]e are not absolute and outright owners of ourselves; the only being who owns us in that way is God," Alan Ryan writes, adding that "we have something like a lease in ourselves."12 All natural rights, Jennifer Welchman claims, "accrue from God's grant or concession to us of our lives, our bodies, and our world."13 Self-owners would thus like tenants hold "the right to the use and the fruits of another person's property, with the duty to preserve its substance." 14

In a series of recent publications Adam Seagrave has rejected this popular reconciliatory strategy. He concedes that God has entrusted humans with liberty-rights to use the world and its resources: "in respect of God the Maker of Heaven and Earth, who is sole Lord and Proprietor of the whole World, Man's Propriety in the Creatures is nothing but that Liberty to use them, which God has permitted" (FT §39). Yet Locke nowhere says that our rights in our person are limited to use alone. On the contrary, individuals are depicted in such a way that each is the "absolute Lord of his own Person and Possessions, equal to the greatest, and subject to no Body," free to dispose of his person as he wishes (ST §123). For this reason,

${ }^{10}$ Zuckert, Natural Rights, 241-42. Zuckert's point is not, I take it, that one becomes a selfowner by forfeiting one's life, as Stanley C. Brubaker suggests in "Coming into One's Own: John Locke's Theory of Property, God, and Politics," The Review of Politics 74, no. 2 (2012): 214-15. Rather, the permission to commit suicide putatively shows that we owned our lives all along.

${ }^{11}$ Brian Tierney, "Historical Roots of Modern Rights: Before Locke and After," Ave Maria Law Review 3 (2005): 32.

${ }^{12}$ Alan Ryan, On Politics: A History of Political Thought from Herodotus to the Present (New York: Penguin, 2012), 471.

${ }_{13}$ Jennifer Welchman, "Locke on Slavery and Inalienable Rights," Canadian Journal of Philosophy 25, no. 1 (1995): 75. Also, e.g., Attracta Ingram, A Political Theory of Rights (Oxford: Clarendon Press, 1994), 32.

${ }^{14}$ Justinian's Institutes, ed. Peter Birks and Grant McLeod (London: Duckworth, 1987), 2.4. 
Seagrave maintains, we must dismiss the so-called "tenant" interpretation of human ownership. ${ }^{15}$

Seagrave's alternative solution invokes a distinction from the ECHU. Individuals would have a twofold structure: they can be viewed under the aspect of "substance-man" and of "person-self." "While God makes and owns the individual considered as a 'substance-man' the individual considered as a 'person-self' makes and owns herself."16 On Seagrave's reading, humans literally make their own person and actions by "appropriating, extending, and joining activity or 'labor' of consciousness." 17 Just as God begets ownership by creating "substance-man," so do we come to own ourselves by creating our own person and actions. God has created humans "as potential self-owners." ${ }^{18}$ Like proponents of the tenant interpretation, Seagrave holds that God and humans have property rights in the self-same object. But he departs from that interpretation by insisting that the "property which the human being possesses in himself is identical in kind with the property which God possesses in the human being."19 It is not a lesser property right, like use or usufruct. ${ }^{20}$ In Seagrave's view, full human self-ownership is compatible with, because nested within, full divine proprietorship.

Common to all these readings, and indeed the source of the conundrum, is the supposition of "the coexistence of Divine and human ownership or property with respect to the same object." 21 This assumption of concurrent ownership in the self-same subject, I argue, must be rejected. The next section develops Jeremy Waldron's and James Tully's suggestion that humans are the sole owners of their person, while God owns their lives. "God is the proprietor of man because .. . God makes man. Man on the other hand . . . is the proprietor of his person and . . . of the actions of his person." 22 If my proposal is sound, then the rival tenant and nested interpretations are each half-right and half-wrong-albeit in obverse ways. Our rights in our life are limited to possession, use, and usufruct,

${ }^{15}$ S. Adam Seagrave, "Locke on the Law of Nature and Natural Rights," in A Companion to Locke, ed. Matthew Stuart (Malden, MA: Wiley-Blackwell, 2016), 380-83; S. Adam Seagrave, The Foundations of Natural Morality: On the Compatibility of Natural Rights and the Natural Law (Chicago: University of Chicago Press, 2014), 40-47.

16 S. Adam Seagrave, "Self-Ownership and Divine Ownership: A Lockean Solution to a Liberal Democratic Dilemma," American Journal of Political Science 55, no. 3 (2011): 713; Seagrave, "Locke on the Law of Nature," 384-86.

17 Seagrave, "Self-Ownership," 720.

${ }^{18}$ Ibid., 720; Seagrave, "Locke on the Law of Nature," 386.

19 Seagrave, The Foundations of Natural Morality, 51, emphasis added.

${ }^{20}$ Seagrave thus provides a complex aspectual reading. For another aspectual reading, see Ruth W. Grant, John Locke's Liberalism (Chicago: University of Chicago Press, 1987), 69-71.

${ }^{21}$ Seagrave, "Self-Ownership," 715; Seagrave, "Locke on the Law of Nature," 379-84.

22 James Tully, A Discourse on Property: John Locke and His Adversaries (Cambridge: Cambridge University Press, 1980), 105. Also, Jeremy Waldron, A Right to Private Property (Oxford: Clarendon Press, 1988), 177-83; Janet Coleman, "Pre-Modern Property and Self-Ownership Before and After Locke; or, When Did Common Decency Become a Private Rather than a Public Virtue," European Journal of Political Theory 4, no. 2 (2005): 125-45. 
as the tenant interpretation correctly implies. ${ }^{23}$ But we initially have full rights in our person, as Seagrave accurately observes. To establish the meaning and coherence of this suggestion, the next section explores different senses of personhood across Locke's corpus.

\section{The Meaning of "Person"}

The idea that all human life belongs to God in virtue of His creation is a cornerstone of Locke's moral and political theory. "An All-wise Contriver," we read in the First Treatise, "has so visible a claim on us as his Workmanship" (FT §53; cf. FT §30). Already in the Essays on the Law of Nature (c. 1663-64) Locke had averred that creation gives God authority over us. "God has created us out of nothing and, if he pleases, he will reduce us again to nothing: we are, therefore, subject to him in perfect justice and by utmost necessity" (ELN 119). However, Locke did not yet endorse divine ownership of human life in the Essays. Rather, creation endows God with a general right to govern us:

God ... has such authority and power over us as we cannot exercise over ourselves, and since we owe our body, soul, and life-whatever we are, whatever we have, and even whatever we can be-to him and to him alone, it is proper that we should live according to the precept of his will. (ELN 119)

This argument differs substantively from that found in the Second Treatise. God's "right of creation" (ELN 117) is compatible with us merely having a duty of gratitude to serve Him. The Essays do not argue that humans must preserve themselves and the rest of humanity on pain of violating God's ownership rights in their lives (Section IV). Duties of self-preservation are rather established by God's will and discovered by teleological reflection on the human predicament. Nor do the Essays distinguish between life and person.

That distinction is present in An Essay Concerning Human Understanding (1689). That text reiterates the idea that "God has given a Rule whereby Men should govern themselves" (that is, natural law). For "He has a Right to do it, we are his Creatures," and the power to enforce his commands: "for no body can take us out of his hands" (ECHU 2.28.8). Locke again claims God's existence is demonstrated by the signs of design seen everywhere (ECHU 1.4.9, 4.10). And he again calls us God's "Workmanship" (ECHU 4.10.18).

${ }^{23}$ Tully, A Discourse on Property, 114: "Locke is ... not inconsistent in saying that man's life is both God's and man's property ... It belongs to both, but in different ways: man's property is the right to use and preserve what is essentially God's property, similar to a tenant's property" (emphasis added). 
New to ECHU is a lengthy discussion of the distinct meanings of "person," "substance," and "man" in the context of the metaphysics of personal identity (ECHU 2.27.7). Human beings are made up of two substances: matter and finite intelligence (ECHU 2.27.2). The term "man" denotes a "corporeal rational Creature" of humanlike shape (ECHU 3.11.16). The conceptual possibility of transmigration of souls proves the ideas of "sameness of soul" and "sameness of man" dissimilar. For if Heliogabalus's soul would reincarnate in a pig, few "would yet say that Hog were a Man or Heliogabalus" (ECHU 2.27.6). A person "is a thinking intelligent Being, that has reason and reflection, and can consider it self as it self, the same thinking thing in different times." Personal identity is thus "the sameness of a rational Being" over time (ECHU 2.27.9).

Driving Locke's account of personal identity is the justification of otherworldly rewards and punishments (ECHU 2.27.18). Divine justice requires that we still be the same persons on the Great Day of Reckoning as we are now. This theological desideratum informs Locke's analysis of "person": "it is a Forensick Term appropriating Actions and their Merit; and so belongs only to intelligent Agents capable of a Law, and Happiness and Misery" (ECHU 2.27.26). Persons are conscious selves to whom actions can be ascribed and for which that self can be held accountable. Linking personal identity to continuity in "substance" or "man" will not do since bodies change and people die. Our souls might be in a disembodied state on the Day of Judgment or incarnated in even-toed ungulates. Personal identity persists even as the substances composing us change (as happens upon death) (ECHU 2.27.11). What rather preserves personal identity over time, Locke argues, is consciousness. "The same consciousness uniting those distant Actions into the same Person, whatever Substances contributed to their Production" (ECHU 2.27.10). Moral accountability toward God, after all, presupposes awareness of past deeds.

Accountability is explained in terms of "owning" one's actions. "This personality extends it self beyond present Existence to what is past, only by consciousness, whereby it becomes concerned and accountable, owns and imputes to it self past Actions" (ECHU 2.27.26). "Persons" are thus foremost stable moral ascription points capable of giving account of their actions after their bodily demise. One acute observer has concluded that "Locke's idea of moral man appears, then, to be related to the legal idea of person, of 'a subject of legal rights and duties'."24 We could indeed say that Locke moralizes the legal notion of personhood to capture relations of accountability toward God. Our person, in this sense, is evidently nonidentical to our life. God can rightly wipe away our life in a blink without affecting our personhood, which persists, keeping us answerable for our every deed.

${ }^{24}$ David P. Behan, "Locke on Persons and Personal Identity," Canadian Journal of Philosophy 9, no. 1 (1979): 61-62. Cf. Margaret Jane Radin, "Property and Personhood," Stanford Law Review 35, no. 5 (1982): 962-63. 
Tully has argued that Locke's exposition of person found in ECHU is key to understanding the idea of self-proprietorship in the Two Treatises. ${ }^{25}$ Personhood requires the capacity of free and intentional action. Just as God holds "makers' rights" in his creation, so each human "comes to have a natural and exclusive right in the actions he makes as a person." 26 I will here leave undiscussed Tully's "maker's rights"-interpretation of the foundations of Lockean property rights. ${ }^{27}$ Instead, I will criticize Tully's suggestion that Locke has a single conception of "person," found in both ECHU and the Two Treatises. Locke in fact uses the term "person" in two irreducibly distinct senses, both nonidentical with life. "Person" either denotes: 1) a morally accountable self-the "moral man"; or 2) "what is owned by that individual-his moral property." ${ }^{28}$ Call them "moral" and "legal" personhood for short. Moral personhood, a presupposition of moral accountability, is prevalent in the ECHU. The legal meaning of personhood is salient in the Two Treatises.

Each human being is born, Locke writes, with "A Right of Freedom to his Person, which no other Man has a Power over, but the free Disposal of it lies in himself" (ST §190). For Locke, the power to dispose (ius alieni) is essential to property. Things must be "their own, and at their own dispose, and not at his; or else it is no property" (ST §194). ${ }^{29}$ How can an individual simultaneously be a person and be a proprietor of his person if ownership essentially includes rights of disposal? These statements are highly puzzling if, following Tully, we identify the freely acting moral agent with the person she owns. ${ }^{30}$ For Locke would then be claiming that self-owners have a power to freely dispose of their selves. That would contradict both the prohibition against suicide and the persistence of personal identity in the hereafter. What then does the absolute original right in one's person and the "uncontroleable Liberty, to dispose of his Person" mean (ST §6)? What is being disposed when one disposes of one's person?

To answer these questions, we must turn to Locke's polemics with Filmer. Filmer rejected the axiom of human natural freedom underlying the social contract of government. We are all born in subjection, owing lifelong obedience to our fathers from birth. The right to rule, he argued, is nothing other than the absolute and arbitrary right that fathers putatively have over their offspring. The biblical donation of dominium over nonhuman animals was interpreted by Filmer as proof that Adam had "by right

\footnotetext{
25 Tully, A Discourse on Property, 106-111.

${ }^{26}$ Ibid., 109.

${ }^{27}$ For a searching critique, see A. John Simmons, "Makers' Rights," The Journal of Ethics 2, no. 3 (1998): 197-218.

28 Behan, "Locke on Persons," 67.

${ }^{29}$ The commonplace that ius alieni is essential to private property traces back at least to Aristotle, Rhetoric $1.5\left(1361^{\mathrm{a}}\right)$ : "[something] is our own if it is in our power to dispose of it or not."

${ }^{30}$ Tully, A Discourse on Property, 111.
} 
of fatherhood, royal authority over his children." 31 This right, "as large and as ample as the absolutest dominion of any monarch," had subsequently been passed on to successor patriarch kings. ${ }^{32}$ Filmer thus treated all authority as identical in kind. Kingly power simply is fatherly power. Indeed, "a son, a subject, and a servant or a slave, were one and the same thing at first." 33 Moreover, all rule is essentially despotic, arbitrary, and absolute: no subject is accorded the advantage of private property-not even in his own person.

Locke balked at this. He chided Filmer for granting to rulers

a Divine unalterable Right of Sovereignty, whereby a Father or a Prince hath an Absolute, Arbitrary, Unlimited, and Unlimitable Power, over the Lives, Liberties, and Estates of his Children and Subjects; so that he may take or alienate their Estates, sell, castrate, or use their Persons as he pleases, they being all his Slaves, and he Lord or Proprietor of every Thing, and his unbounded Will their Law. (FT §9)

Locke concurred that parental rule is "a natural Government" but dismissed Filmer's equation of paternal with political rule (ST §170). Locke was adamant that everyone equally is born free from political authority. "Man being born ... with a Title to perfect Freedom, and an uncontrouled enjoyment of all the Rights and Priviledges of the Law of Nature, equally with any other Man" (ST §87). Children are subject to the natural government of their parents, entailing natural obligations of obedience. ${ }^{34}$ But, Locke insisted, once anyone comes of age, "then he is a Free-man, at liberty what Government he will put himself under; what Body Politick he will unite himself to" (ST §118; also, ST §57). Original property in one's person is thus expressive of human natural freedom from civil subjection. All forms of civil subordination are the consequence of individual actions (engaging in commitments or crime).

What does the liberty to freely dispose of one's person mean? Out of sociable inclinations and to avoid the dangers inseparable from life without civil government each individual voluntarily chooses to "unite his Person, which was before free, to any Commonwealth; by the same he unites his Possessions, which were before free, to it also; and they become, both of them, Person and Possession, subject to the Government and Dominion

\footnotetext{
${ }^{31}$ Robert Filmer, Patriarcha and Other Writings, ed. Johann P. Sommerville (Cambridge: Cambridge University Press, 1991), 6.

32 Ibid., 7 .

${ }^{33}$ Ibid., 237.

${ }^{34}$ Cf. ST §55: "Children, I confess are not born in this full state of Equality, though they are born to it" (emphasis added). Following Grotius, Locke challenged Filmer's contention that children never become independent from their living fathers (ST §§55-67). James Tyrrell did the same in Patriarcha non Monarcha (London: Richard Janeway, 1681), 18-19. Hugo Grotius, The Rights of War and Peace, Volumes 1-3, ed. Richard Tuck (Indianapolis, IN: Liberty Fund, 2005), 2.5.2.1.
} 
of that Commonwealth" (ST §120). The natural freedom of each to dispose his person and possessions as he wishes is, then, no admonishment to suicide but simply the right to choose one's own political rulers and masters (and an immunity against anyone else imposing a master upon one). All civil authority originates in the consent of self-owners. ${ }^{35}$ Personal self-ownership thus both presupposes original freedom from civil subjection and uniquely entitles individuals to consensually enter such conditions of subjection. Freely disposing of one's person does not involve alienating or extinguishing one's legal personhood. Rather, it is the free acceptance of personal subjection to some self-chosen authority (in marriage, employment, or politics), who in turn acquires a right to govern one's person.

In claiming that individuals are initially proprietors of their own person Locke advances what has been called a "proprietary" conception of rights. ${ }^{36}$ The idea that every person stands "in a relation of dominium to his own dominium," that is, "has property in his rights" and can hence sell and otherwise alienate them, was a scholastic commonplace. ${ }^{37}$ Observe, though, that Lockean individuals do not fully renounce their person and possessions upon entering political society. ${ }^{38}$ That would defeat the purpose of civil subjection, which is "the mutual Preservation of their Lives, Liberties and Estates, which I call by the general Name, Property" (ST §123; also, ST §138). Rather, humans place their person and property under civil jurisdiction, to be regulated by laws for the common good (ST §50). Such regulation will involve taxation and other restrictions of individual liberties and property rights, justified by the need to secure the rights of all.

Political rulers hence do not come to own the persons of their subjects. They rather acquire a directive power over these persons, correlating in citizens' obligations of obedience. Operative here is Aristotle's distinction in Politics (1255b16-20) between the political government of a statesman (politikos) over free and equal persons and the domestic rule of the master (despotes) over slaves. ${ }^{39}$ Following Aristotle, Locke characterized political rule as the power of "Governours" who govern by public consent and "for the Benefit of their Subjects, to secure them in the Possession and Use of their Properties" (ST §173). Power is properly called "political"

${ }^{35}$ For example, ST §95, §117, §119, §192.

36 Pateman, "Self-Ownership and Property in the Person," 49.

${ }^{37}$ Annabel Brett, "Individual and Community in the 'Second Scholastic': Subjective Rights in Domingo de Soto and Francisco Suárez," in Philosophy in the Sixteenth and Seventeenth Centuries: Conversations with Aristotle, ed. Constance Blackwell and Sachiko Kusukawa (Aldershot: Ashgate, 1999), 163.

38 As argued by Tully, A Discourse on Property, 164. For critical discussion of Tully's "Rousseauian" reading, see Jeremy Waldron, "Locke, Tully, and the Regulation of Property," Political Studies 32 (1984): 98-106.

${ }^{39}$ J. S. Maloy, "The Aristotelianism of Locke's Politics," Journal of the History of Ideas 70, no. 2 (2009): 235-57. 
only because and insofar as it serves to "preserve the Members of that Society in their Lives, Liberties, and Possessions" (ST §171). Despotic power, conversely, is the power of "Lords" who rule "for their own Benefit, over those who are Stripp'd of all property" - "which Men have in their Persons as well as Goods" (ST §173). Despotic and political power are fundamentally distinct in origin and character. Political rule is not the rule of the dominus. Indeed, "Absolute Monarchy... can be no Form of Civil Government at all" (ST §90; also, ST §174).

Lockean slaves have lost their legal personality entirely and hence lack any legal standing, as in Roman law. ${ }^{40}$ Lacking all rights and property, even in their persons, they may be killed at will. Locke defines "Despotical Power" — the power of a master over her slave-as "an Absolute Power one Man has over another, to take away his Life, whenever he pleases" (ST §172). Despotic power can justly be acquired only over someone who has "by his fault, forfeited his own Life, by some Act that deserves Death" (ST \$23). Since slaves are "not capable of any Property," they therefore "cannot in that state be considered as any part of Civil Society; the chief end whereof is the preservation of Property" (ST §85). Section V further explores Locke's justification of penal slavery.

When Locke claims that slaves have no legal standing, his point is not that they need not worry about Doomsday. Slaves are not absolved of giving moral account of themselves for having lost legal personality. The same holds for minors and married women (insofar as they would lack legal personality). Personhood vis-à-vis God is independent from being legally sui juris. But don't our persons belong to God? Recall my distinction between moral and legal personhood. In neither sense, I contend, does God own our persons. He certainly has the right to rule us; our persons are under divine jurisdiction. That government expresses itself in accountability to him for the moral quality of our actions. Now, God cannot coherently own our "moral person" and hold us accountable for our moral conduct. For being a moral person just is being held subject to the moral law. Neither can God freely dispose of our legal personhood. Humans are entitled to freely and voluntarily limit their independence by agreeing to submit to the power (potestas) of another: a political ruler, boss, or husband (Locke maintains). God clearly cannot marry me off or subject me to some political regime. God has the right and power to sanction compliance with moral law with threats of otherworldly bliss or doom. He also has another lawful power: to reclaim our present lives at will. We have no standing to complain to God for not being given a longer sojourn in this

${ }^{40}$ For example, Justinian's Institutes 1.16.4; Digest 50.17.32. William Warwick Buckland highlights the dual status of slaves as both things and human beings in The Roman Law of Slavery: The Condition of the Slave in Private Law from Augustus to Justinian (Cambridge: Cambridge University Press, 1970 [1908]), 1-238. 
vale of tears. Yet God has this latter power in virtue of owning our lives, rather than our persons. ${ }^{41}$

Original proprietorship of our person and divine ownership of human life are compatible, I have argued, because the former by no means captures all the rights humans can have in themselves. It merely expresses an original right of self-government and natural freedom from civil subjection. The next section explores what implications divine ownership of human life has for personal self-ownership.

\section{How Divine Dominium Delimits Lawful Personal Subjection}

Divine ownership of human life is the mainstay of Locke's moral and political theory. It grounds, first, the natural law duty to preserve oneself and the rest of humanity. The "Fundamental Law of Nature and Government" dictates that "all the Members of the Society are to be preserved" on pain of transgressing God's property rights (ST §159). ${ }^{42}$ The duty to preserve ourselves is a direct corollary of Locke's restriction of property rights in our life to exclusive possession, use, and usufruct. These rights hence fall short of full ownership, which is captured by the trivium usus, usufructus, abusus. Since our life is not ours, "no Body has an Absolute Arbitrary Power over himself, or over any other, to destroy his own Life, or take away the Life or Property of Another" (ST \$135). Murder and suicide are impermissible because they violate God's ownership rights in our lives.

Second, divine ownership generates rights of self-preservation and selfdefense: "they will always have a right to preserve what they have not a Power to part with; and to rid themselves of those who invade this Fundamental, Sacred, and unalterable Law of Self-Preservation" (ST §149). Individual claim-rights to life and limb are the correlates of the general duty not to impair God's property without His permission. "To have rights against other human beings, rights understood as derivative from the primary natural law duties, means to be the beneficiary of the others' natural law duties." 43

A third major implication of divine ownership of human life is the impossibility of self-enslavement. Lockean slavery is an unusually vile condition. ${ }^{44}$ Masters have an "Absolute, Arbitrary, Despotical Power"

${ }^{41}$ Brubaker, "Coming into One's Own," 217, deems it significant that Locke calls humans God's servants rather than his slaves (ST §6). For "servants own themselves, slaves do not." As evidence for the normative relation between humans and God, the point cannot be pushed too far. While masters have power of life and death over slaves but not over servants, God indisputably has the absolute power to take our life at will. Brubaker's point becomes obsolete once we recognize that God exercises the latter power in virtue of owning our lives.

42 Also, ST §§6-7, §16, §134, §171.

${ }^{43}$ Zuckert, Natural Rights, 244.

${ }^{44}$ On Locke's idiosyncratic conception of slavery, see Johan Olsthoorn and Laurens van Apeldoorn, "This Man is My Property': Slavery and Political Absolutism in Locke and the Classical Social Contract Tradition" (manuscript on file with the author). 
over their slaves, including a "power to kill him, at any time" (ST §24). It is impossible for Lockean individuals to voluntarily enter such forms of subjection:

For a Man, not having the Power of his own Life, cannot, by Compact, or his own Consent, enslave himself to any one, nor put himself under the Absolute, Arbitrary Power of another, to take away his Life, when he pleases. No body can give more Power than he has himself; and he that cannot take away his own Life, cannot give another power over it. (ST §23)

The impossibility of self-enslavement extends to the consensual establishment of all despotic power, including absolute monarchy.

Fourth, divine dominium delimits which powers individuals can hand over to government. Killing or harming innocent fellow-humans violates God's ownership rights: we neither own our life, nor that of others. Citizens cannot authorize the government to harm innocent subjects since they lack this power themselves.

A Man ... cannot subject himself to the Arbitrary Power of another; and having in the State of Nature no Arbitrary Power over the Life, Liberty, or Possession of another, but only so much as the Law of Nature gave him for the preservation of himself, and the rest of Mankind; this is all he doth, or can give up to the Common-wealth, and by it to the Legislative Power, so that the Legislative can have no more than this. (ST §135)

This section analyzes the normative implications of divine proprietorship through the lens of the "life versus person" distinction. I argue that rights and duties of self-preservation restrict how we can dispose of our person, rendering certain pacts of subjection morally out of bounds. My argument, I should stress, concerns the possibility of disposing of our person, not our life/body. I have already established that Locke rejects full self-ownership of one's life. I will now argue that Locke also dismisses full original self-ownership of one's person.

To fully grasp the structure of Locke's theory of human and divine ownership, it helps to distinguish between two kinds of restrictions on property rights. ${ }^{45}$ Some rights-delimitations are internal to property: the property rights we have in virtue of owning a thing are less extensive then they could logically be. Lockean rights in life are a case in point: we were never given full ownership of our life, including rights of

45 Johan Olsthoorn, "Two Ways of Theorizing Collective Ownership of the Earth," in Property Theory: Legal and Political Perspectives, ed. James Penner and Michael Otsuka (Cambridge: Cambridge University Press, 2018), 189-90. 
destruction, to begin with. Other delimitations are external to property rights. External moral norms, informed by some moral value or another, can place limits on what we may do with our property. For instance, duties of care to dependents may render it morally impermissible for me to kill myself. The difference between internal and external restrictions is not the extent of our rights-these might be equally curtailed. The distinction rather concerns the source and nature of rights-restrictions. Consider: I might have no right to wreck the Cézanne painting I own because I bought it on condition that I will preserve it (internal restriction). The property rights I have acquired in the painting were, in that case, never so expansive as to include a right of destruction. Alternatively, wrecking the Cézanne might be morally impermissible because of its exceptional artistic value (external limitation). Internal restrictions determine the extent of our property rights-what we have moral title to in virtue of owning a thing. External limitations impose moral duties on conduct-what we are morally entitled to do with our property. These duties are external to property rights.

This distinction allows us to see that Locke argues, not for the moral impermissibility of instituting despotic rule, but for its impossibility. Consider this passage:

it being out of a Man's power so to submit himself to another, as to give him a liberty to destroy him; God and Nature never allowing a Man so to abandon himself, as to neglect his own preservation: And since he cannot take away his own Life, neither can he give another power to take it (ST §168).

Locke makes two claims here: 1) we have a moral duty to preserve ourselves; 2) we cannot transfer to another the right to kill us since we ourselves lack this power. The first claim states that suicide is morally impermissible, not that it is somehow impossible. By contrast, granting another the right to kill us at will is not so much morally forbidden, as impossible. "[N]o Man can, by agreement, pass over to another that which he hath not in himself, a Power over his own Life" (ST §24).46 Observe that Locke's "impossibility" thesis trades on the idea that divine ownership of human life creates an internal restriction on our property rights in our life. Locke's claim is not that natural law renders self-enslavement impermissible (external restriction). Rather, he maintains that the property rights in our life we have received were never so expansive as to include the ius alieni (right of transfer and destruction), rendering self-enslavement impossible (internal restriction).

\footnotetext{
${ }^{46}$ As the Roman law maxim has it, "no one can transfer to another a right which he himself does not possess" (Digest 50.17.54).
} 
The political implications of Locke's prohibition of suicide are amply recognized in the literature. ${ }^{47}$ The "life versus person" distinction allows for a sharper analysis of Locke's argument than is extant. Humans, I have suggested, have been given limited property rights in their life-possession, use, and usufruct. To intentionally destroy one's life or that of an innocent other violates God's ownership rights in all human life; for this reason, natural law commands us to preserve ourselves and the rest of humanity (as far as possible). Because we lack ultimate ownership of our lives, we cannot voluntarily enter conditions of absolute subjection. On the reading proposed here, humans have a natural right of disposal in their own person-each is by nature "absolute Lord of his own Person and Possessions" (ST §123). As personal self-owners, we can generally transfer the right to govern us to whomever and in whichever way we please- with one big exception: we cannot consent to despotic rule. Despotic rulers have the moral power, Locke avers, to kill their subjects at any time (ST §24). Voluntary subjection to despotism is impossible since it presupposes transference of a power of life and death that we lack.

Divine ownership of human life, I have argued, restricts what kinds of subjection humans can agree to. Just as it is impossible to alienate our rights to self-preservation and self-defense, so we cannot dispose of our persons in a way that amounts to relinquishing such rights to another. ${ }^{48}$ For this reason, we can never formally place our persons under the jurisdiction of an absolute monarch, wielding the arbitrary power of life and death. Locke, I have contended, defends the impossibility, rather than the moral impermissibility, of instituting despotic rule. It follows that divine ownership of human life internally curbs our general right to freely dispose our persons as we wish. The rights we have in virtue of owning our persons are not as ample as full ownership rights.

\section{Forfeiting Your Life: Capital Punishment and Penal SLAVERY}

The Second Treatise contains a rather startling theory of rights-forfeiture (involuntary loss through wrongdoing). In the state of nature, anyone guilty of using unjust force becomes liable to be killed by anyone else. For the unjust aggressor forfeits his life. "Tis the unjust use of force then, that puts a Man into the state of War with another, and thereby he, that is guilty of it, makes a forfeiture of his Life" (ST §181). More distressingly, unjust aggressors may lawfully be enslaved by the persons they have injured,

\footnotetext{
${ }^{47}$ For example, Gary D. Glenn, "Inalienable Rights and Locke's Argument for Limited Government: Political Implications of a Right to Suicide," The Journal of Politics 46, no. 1 (1984): 80-105; A. John Simmons, "Inalienable Rights and Locke's Treatises," Philosophy and Public Affairs 12, no. 3 (1983): 175-204.

${ }^{48}$ For an argument, citing Locke, that nonwaivable rights in ourselves are by definition not rights of self-ownership, see Hillel Steiner, An Essay on Rights (Oxford: Blackwell, 1994), 232-33.
} 
to compensate for harm done. "Indeed having, by his fault, forfeited his own Life, by some Act that deserves Death; he, to whom he has forfeited it, may (when he has him in his Power) delay to take it, and make use of him to his own Service, and he does him no injury by it" (ST §23). How can Locke coherently endorse penal slavery while insisting that self-owners have a natural right of self-government?

Locke's endorsement of a rights-forfeiture theory of crime raises many questions. ${ }^{49}$ Some concern the very possibility of forfeiture. How does rights-forfeiture chime with divine ownership of human life and proprietorship of one's person? How can we forfeit something-our life-that was never ours to begin with? And if we cannot directly alienate our life to someone else, how come we can act in such a way as to forfeit it to another? Others concern the normative consequences of forfeiture. What kind of rights do masters acquire in their slaves? And if all of us may kill unjust aggressors outside the commonwealth, why cannot we all permissibly enslave unjust aggressors as well?

This section contends that divine dominium of human life underpins the justifiability of penal slavery-just as it grounds the impossibility of selfenslavement. I argue that the law of nature authorizes each individual to punish by death anyone who has forfeited his life through unjust aggression. Yet only the injured party can claim the aggressor's goods or service in compensation for harm done to her. If the injured party chooses to exercise this right and enslave the unjust aggressor, then she acquires "a Despotical Right over the Person" of the aggressor (ST §196). Despotic right includes the "Absolute, Arbitrary Power ... to take away his Life, whenever he pleases" (ST §172). People can justly hold such arbitrary power only over individuals who had previously forfeited their life. Peculiarly, Locke conceives of the master-slave relation in just war terms: masters hold the power of life and death over their slaves by the right of war.

In the state of nature, "every Man hath a Right to punish the Offender, and be Executioner of the Law of Nature" (ST §8; also, ST §87; ST §128). Locke concedes that this may seem "a very strange Doctrine" to some (ST §9). Very few philosophers before Locke had endorsed a natural right to punish of any kind (Grotius being the main exception). The right to punish was standardly seen as presupposing political authority over the criminal. Granting any such right to mere individuals, equals by nature, was therefore deemed incoherent. ${ }^{50}$ According to Locke, the natural law-which

\footnotetext{
${ }^{49}$ Some of these questions are discussed in Jeremy Waldron, God, Locke, and Equality: Christian Foundations in Locke's Political Thought (Cambridge: Cambridge University Press, 2002), 143-50.

${ }^{50}$ For example, Francisco de Vitoria, Political Writings, ed. Anthony Pagden and Jeremy Lawrance (Cambridge: Cambridge University Press, 1991), 300; Alberico Gentili, De Jure Belli Libri Tres, Volumes 1-2, ed. John C. Rolfe (Oxford: Clarendon Press, 1933), 41; Francisco Suárez, "A Work on the Three Theological Virtues: Faith, Hope and Charity," in Selections from Three Works, Volumes 1-2, ed. Gwladys L. Williams, Ammi Brown, and John Waldron (Oxford: Clarendon Press, 1944), 818. Cf. Grotius, The Rights of War and Peace, 2.20.9.
} 
commands us to do our utmost to preserve ourselves and the rest of humanity—gives all and sundry "a right to punish the transgressors of that Law to such a Degree, as may hinder its Violation" (ST §7). This universal right to punish for the sake of deterrence is conditional on the aggressor's liability to be killed (ST §172). The right is not, however, constituted by or derived from the aggressor's forfeiture of his life. ${ }^{51}$

Locke, I suggest, was working with the received twin Roman law categories of rights in things and rights against persons. The two categories are mutually exclusive. Rights in things hold against the world (as legal theorists are wont to say): your privileged relation to the thing owned grounds obligations imposed on everyone else. By contrast, rights against persons are bilateral and grounded in the distinctive normative relation in which you and I stand. To forfeit a right in a thing (say, in your life) thus means forgoing standing against the world. Aggressors can consequently no longer claim to possess a right to life against anyone. This follows directly from the juridical shape property rights in things have. Conversely, forfeiting my personal right against you (say, that you keep your promise) has no normative consequences for third parties. Attesting to his endorsement of the pre-Hohfeldian idea of rights in things, Locke consistently speaks of forfeiting one's life-not of forfeiting one's right to life (correlating in obligations others owe you). ${ }^{52}$ Unjust aggressors entirely forgo the limited property rights they had in their life.

By forgoing their lives, unjust aggressors also forgo their right of self-preservation. That right can be seen as the upshot of natural law duties of everyone else not to destroy God's property without His permission. We ought to preserve ourselves and humanity because it is wrong to destroy what belongs to another without their consent. The natural right to punish criminal offenders can be understood as a divine authorization to demolish God's property. By forfeiting their lives, unjust aggressors thus annul the natural law duties on everyone else not to destroy this part of God's creation.

The deterrence ("restraint") justification for rights of punishment does not sanction seizing possession of the person and goods of the aggressor. ${ }^{53}$ While the right "of Punishing the Crime for restraint . . . is in every body," the right "of taking reparation ... belongs only to the injured party" (ST §11).

\footnotetext{
${ }^{51}$ A. John Simmons, "Locke on the Death Penalty," Philosophy 69, no. 270 (1994): 475: “"The right to be the party that does the punishing', however, does not derive from forfeiture. In the state of nature it derives from God's authorization of mankind to enforce His law, and so is a right shared by all."

${ }^{52}$ ST $§ 23, \S 85, \S 172, \S \S 178-83$.

${ }^{53}$ On Locke's right to punish, see e.g., A. John Simmons, "Locke and the Right to Punish," Philosophy and Public Affairs 20, no. 4 (1991): 311-49; Brian Calvert, "Locke on Punishment and the Death Penalty," Philosophy 68, no. 264 (1993): 211-29; Alex Tuckness, "Retribution and Restitution in Locke's Theory of Punishment," The Journal of Politics 72, no. 3 (2010): $720-32$.
} 
The victim is uniquely entitled to seize the aggressor's goods and labor by right of self-preservation. ${ }^{54}$

The damnified [that is, injured] Person has this Power of appropriating to himself, the Goods or Service of the Offender, by Right of Self-preservation, as every Man has a Power to punish the Crime, to prevent its being committed again, by the Right he has of Preserving all Mankind. (ST §11; also, ST §183)

How self-preservation exactly grounds rights of reparation is not entirely clear. Locke is not, I gather, making the Hobbesian claim that our preservation is better served by seeking recovery, but rather the Grotian one that violations of our rights entitle us to seek compensation for harm suffered. ${ }^{55}$ Unlike Grotius, Locke maintains that one way to secure compensation is to enslave the culpable aggressor. The remedial right to enslave unjust aggressors requires that the latter are liable to greater punishments (ST §23). But the right is not grounded in their liability. Rather, self-preservation entitles individuals to seek compensation for unjustly suffered harm. Locke reiterates the same point in his discussion of just conquest. Any victim of unjust aggression "by Conquest has a right over a Man's Person to destroy him if he pleases," but "has not thereby a right over his Estate to possess and enjoy it." For only "damage sustain'd ... gives him Title to another Mans Goods ... His force, and the state of War he put himself in, made him forfeit his Life, but gave me no Title to his Goods" (ST §182; also, ST §180).

This last passage could be read as evidence that Locke's "bestialization of offenders" should not be taken literally. ${ }^{56}$ While unjust aggressors "may be destroyed as ... one of those wild Savage Beasts, with whom Men can have no Society nor Security" (ST §11), such "animals" do not lose all rights, it seems-only the right to life. The evidence is not decisive. That the victim does not acquire rights in the aggressor's estates does not mean that the aggressor retains those rights. Locke mentions rights of dependents immediately after: "My wife had a share in my Estate, that neither could I forfeit. And my Children also, being born of me, had a right to be maintained out of my Labour or Substance" (ST §183). The aggressor might thus well have forfeited all his rights, though not those of his family.

The bestialization reading is bolstered by Locke's claim that despotic power is "over such as have no property at all" (ST §174; also, ST §85).

${ }^{54}$ Welchman overlooks this distinction in "Locke on Slavery and Inalienable Rights," 78-79. Locke justifies penal slavery for reasons of compensation-not deterrence, as Welchman avers.

${ }^{55}$ Grotius, The Rights of War and Peace, 2.17.1.

56 Waldron, God, Locke, and Equality, 146. Also, John Dunn, The Political Thought of John Locke: An Historical Account of the Argument of the 'Two Treatises of Government' (Cambridge: Cambridge University Press, 1969), 107. Cf. Rebecca Kingston, "Locke, Waldron and the Moral Status of 'Crooks'," European Journal of Political Theory 7, no. 2 (2008): 209-14. 
Locke advances a just war conception of slavery. The "perfect condition of Slavery ... is nothing else, but the State of War continued, between a lawful Conqueror, and a Captive" (ST \$24). The relations between master and slave are governed not by civil law or private contract but by ius belli: "as soon as Compact enters, Slavery ceases, and he so far quits his Absolute Power, and puts an end to the State of War, who enters into Conditions with his Captive" (ST §173). Locke's bellicose conception of slavery might suggest that the master has no governmental power over her slaves whatsoever. Master and slave simply occupy a state of war. The inference is premised on a false dichotomy. Locke's view is that despotic rule consists in rights of war over the persons of unjust aggressors. ${ }^{57}$

Despotic power is a potentially lawful rule over persons (ST §196). It differs essentially from political rule in including the arbitrary power of life and death — a right that can only be acquired by just war. The inability of humans to consent to despotic power does not render it altogether illegitimate. For while humans cannot alienate or renounce their life (never theirs to begin with), they can forfeit it for crime.

Despotical Power is an Absolute, Arbitrary Power one Man has over another, to take away his Life, whenever he pleases. This is a Power, which neither Nature gives . . nor Compact can convey, for Man not having such an Arbitrary Power over his own Life, cannot given another Man such a Power over it; but it is the effect only of Forfeiture, which the Aggressor makes of his own Life, when he puts himself into the state of War with another. (ST §172) ${ }^{58}$

While everyone may kill liable offenders in deterrence, not everyone thereby acquires a right to their personal service. The right to hold the offender in personal subjection accrues only to the just conqueror, "to whom" the criminal has forfeited his life in compensation for harm suffered (ST §23).

My analysis of Locke's rights-forfeiture theory has further elucidated the logical entanglements between divine ownership of human life and self-ownership of one's person. Lockean self-owners are free to subject themselves to whatever civil government they choose-provided such government is compatible with the limited powers they have over their lives. Just conquerors can acquire despotic power over individuals who have forfeited their life through brazen aggression; the power of life and

\footnotetext{
${ }^{57}$ Whether perfect slaves have personal obligations to obey their masters, grounded not in compact but in crime, is unclear. Locke's line of reasoning in ST §§185-187 may make us think so. The standard just war view that unjust aggressors lack the right to forcibly resist just conquerors arguably suffices to establish slaves' duties of compliance.

${ }^{58}$ Locke was aware of the conceptual difference between forfeiture and voluntary alienation/renouncement of right (FT §100). A. John Simmons, On the Edge of Anarchy: Locke, Consent, and the Limits of Society (Princeton, NJ: Princeton University Press, 1993), 46-48.
} 
death thus obtained is a component of a lawful, if extreme, form of government over their persons. Committing capital crimes thus makes people liable to be killed and liable to be involuntarily subjected to another's rule. Divine proprietorship of human life implies that all lawful slavery is penal slavery.

\section{Conclusion}

This essay aspired to illuminate the meaning and normative significance of Locke's theory of self-ownership by exploring the interrelations between self-ownership of one's person and divine proprietorship of human life. I have argued that Locke does not endorse full self-ownership: "the fullest right a person (logically) can have over herself provided that each other person also has just such a right." 59 This holds true regardless of whether we conceive of self-ownership as rights in our person or in our life. My interpretation is fairly uncontroversial regarding life-ownership: God has merely granted us rights of exclusive use and usufruct in our life and body, compatible with ultimate divine ownership. More surprising perhaps is my contention that Locke does not endorse full self-ownership of one's person either.

Lockean "property in one's person," this essay has shown, is a narrower concept than self-ownership standardly understood. The concept does not capture all the rights we can logically have in ourselves-such as over our body, skills, and labor. Rather, Lockean self-ownership expresses that humans, by nature free and independent, are entitled to enter conditions of subjection of their own choosing (when they hit maturity). For Locke, self-ownership is thus a contrastive thesis: nobody—not even God—initially has rights in my person but me. While this makes every human by nature "absolute Lord of his own Person and Possessions, equal to the greatest, and subject to no Body," it does not follow that we therefore have full property in our own person (as Locke understood the term). Divine dominium of human life renders it impossible for us to consensually establish absolute rule since that requires transference of a power that we never had over our own life. Divine proprietorship thus directly restricts the set of rights we have in our life and body, and indirectly curtails rights in our person. Since neither restriction is logically necessitated, I conclude that Locke rejects full self-ownership in both our life and our person.

${ }^{59}$ G. A. Cohen, Self-Ownership, Freedom, and Equality (Cambridge: Cambridge University Press, 1995), 213. Which rights humans have in virtue of being self-owners depends on how the concept is fleshed out, with "full self-ownership" granting to individuals as large a set of property rights in themselves as they can morally have in inanimate objects. Peter Vallentyne and Hillel Steiner, "Introduction: Left-Libertarianism: A Primer," in Vallentyne and Steiner, eds., Left-Libertarianism and Its Critics: The Contemporary Debate (Basingstoke: Palgrave MacMillan, 2000), 2-5. For a critique of the full self-ownership thesis, see David Sobel, "Backing Away from Libertarian Self-Ownership," Ethics 123, no. 1 (2012): 32-60. 
It is noteworthy that Locke invokes a premise external to self-ownership to rule out self-enslavement: divine ownership of human life. This helps explain why modern Lockean philosophers, who have uniformly dismissed Locke's theological assumptions, waver on the issue of self-enslavement. Placing moral limits on the relations people can consensually enter (other than the rights of others) smacks of paternalism. Some libertarians have followed Nozick in biting the bullet: "a free system will allow [an individual] to sell himself into slavery." ${ }^{\prime 60}$ Nozick's concession seems simultaneously in accord with and in violation of the spirit of freedom animating the idea of self-ownership: in accord with, insofar as humans are free to enter any relation they wish (provided they do not violate the rights of others); in violation of, insofar as coercive and oppressive relationships are thus legitimated. Some proponents of self-ownership have sought to define selfownership "in such a way that it does not allow people to sell themselves into slavery." ${ }^{11}$ Critics have cried "ad hoc," insisting that libertarians can have no principled objection to self-enslavement. ${ }^{62}$ Regardless of what we think of this critique, lawful self-enslavement remains a logical possibility as long as we continue to conceive of self-ownership rights along Lockean lines as property rights, which are in principle alienable.

Political Theory, University of Amsterdam; Philosophy, KU Leuven / FWO-Flanders

${ }^{60}$ Robert Nozick, Anarchy, State, and Utopia (Malden, MA: Blackwell, 1974), 331.

${ }^{61}$ Philippe Van Parijs, Real Freedom for All: What (If Anything) Can Justify Capitalism? (Oxford: Clarendon Press, 1995), 234n.

62 E.g. Samuel Freeman, "Illiberal Libertarians: Why Libertarianism is Not a Liberal View," Philosophy and Public Affairs 30, no. 2 (2001): 131-35; David Ellerman, "Inalienable Rights: A Litmus Test for Liberal Theories of Justice," Law and Philosophy 29, no. 5 (2010): 571-99; Debra Satz, Why Some Things Should Not Be for Sale: The Moral Limits of Markets (Oxford: Oxford University Press, 2010), 174-79. 